\title{
CEO Cash Compensation and Firm Performance: An Empirical Study from Emerging Markets
}

\author{
Nana Osei-Bonsu \\ Ajman University of Science \& Technology, Fujairah Campus, UAE \\ E-mail:n.bonsu@ajman.ac.ae \\ Joseph George M. Lutta \\ Ajman University of Science \& Technology, Ajman Campus, UAE \\ E-mail: j.lutta@ajman.ac.ae
}

Received: March 30, 2016 Accepted: April 17, 2016

doi:10.5296/ber.v6i2.9805 URL: http://dx.doi.org/10.5296/ber.v6i2.9805

\begin{abstract}
The primary objective of this study is to examine whether the CEO's cash compensation is influenced by the firm's performance or whether the inverse relationship exists, where the CEO's bonus rather has a positive effect on company performance. The study includes an examination of firms listed on six emerging countries financial markets, and includes separate statistical tests on firms of different sizes and different industry sector. The findings of the study demonstrate that there is no relationship between CEO cash compensation and performance among the firms included in this study. Notwithstanding, some other incentive variables have been found as important performance boosters among companies in certain sectors. This study has been able to establish that some theories of incentive contracts hold true among firms of certain sizes as well as among firms from certain industries.
\end{abstract}

Keywords: CEO, Cash Compensation, Performance, Incentive Contracts

\section{Introduction}

Firm's directors, like most rational human beings, are potentially regarded as risk-averse. The consequences of such a behavior explain that most executives would want their compensation structured in such a way that they bear less personal risk. In order to reduce their "personal" risk, executives may engage in activities that reduce the firm's risk. These activities may adversely affect shareholder's wealth. Executive compensation has been a topic of significant debate for a long period. A lot of this attention has been on Chief Executive Officer (CEO) 
compensation, and its relationship to company performance. Stockholders seem to be more convinced than ever that there is no connection between executive pay and company performance. This criticism has its foundation in growing salaries and bonuses, in times of poor financial conditions and results.

According to agency theory, an agency problem exists when an agent, such as a CEO has established an agenda which conflicts with the interests of the stockholders. In corporations, this means that the board of directors would be unable to confirm that the managers were actually acting in the shareholders' interests because, in most cases managers are insiders with regard to the businesses they operate and thus are better informed than the principals (Dess et al., 2008). The occurrence of a principal agency problem is most likely to happen when an executive has no personal financial interest in the outcomes and decisions made (Boyd, 1994). Managers may, for example, act opportunistically in pursuing their own interests - to the detriment of the corporation. Managers have been known to spend corporate funds on expensive perquisites (e.g., company jets and expensive art), devote time and resources to pet projects (initiatives in which they have a personal interest but that have limited market potential), engage in power struggles, and negate or sabotage attractive merger offers because the latter may result in increased employment risk (Dess et al., 2008). Hence, a solution to the problem of principal agency conflict can be avoided by rewarding the executives on the basis of financial returns to the stockholders. Previous studies by Holmstrom (1979); Harris \& Raviv (1979); Grossman and Hart (1983), suggest that tying executive compensation to firm performance will motivate the executive to make more value-maximizing decisions for the stockholders. Hence, the main objective of this study is to examine empirically if there is a relationship between CEO compensation and firm performance among 260 companies listed on some emerging countries stock market.

\section{Literature Review}

\section{Principal-Agency Theory}

Agency theory is at the core of any research trying to determine whether a correlation exists between performance and executives' pay. The agency theory is concerned with resolving two problems that occur in agency relationships. The first is the agency problem that arises when the goals of the principals (shareholders) and agents (managers) conflict and when it is difficult or expensive for the principal to verify what the agency is actually doing (Dess et al, 2008; Eisenhardt, 1989). The second issue is the problem of risk sharing. According to Eisenhardt (1989), this issue arises when the principals and the agents have different attitudes and preferences toward risk. For instance, the executives in firms may favor additional diversification initiatives because they increase the size of the firm and thus the level of executive compensation. On the other hand, the shareholders may be opposed to such initiatives because of the likelihood of eroding shareholder value (Agawal \& Mandelker, 1987; Dess et al., 2008; Eisenhardt, 1989).

The theory defines how best to categorize relationships in which one party (the principal defined as the Shareholder) determines the work, which another party (the agent defined as the Chief Executive Officer) undertakes (Eisenhardt, 1985). Amongst other concepts, the 
theory argues that under difficult monitoring conditions, such as imperfect information and uncertainty, an agency problem may arise in the form of moral hazard. Problems in moral hazard are common in labor contracting issues. It is the condition under which the principal cannot be sure if the agent has put forth his best effort. Moral Hazard problems can be present any time two parties come into a risk sharing agreement with one another, and where their privately taken actions affect the profitability of the total outcome.

If this situation were to arise, optimal risk sharing is generally excluded since it will not yield the proper incentives for making the correct decision. Moral hazard problems can take the shape of compensation structure. Since the CEO's compensation will be the same regardless of how much or how little the shareholder will benefit from his work, a fixed salary might create a disincentive for taking value maximizing risks and putting forth his best effort. In order to resolve this situation, there needs to be a way to substitute some of the risk sharing where benefits of incentives can be achieved. The action, which is optimal for the agent, will depend on the extent of risk sharing between the principal and the agent (Holstrom, 1979). Incentive contracts can yield the proper stimuli for risk sharing. To entice the Chief Executive Officer to perform to the best of his or her ability, the theory of moral hazard problem suggests replacing fixed wages with compensation that is tied to the profits of the company. The provision of ownership rights according to Goulter (1996) reduces the incentive for executive's moral hazard since it makes their compensation dependent on their performance.

\section{Incentive Contracts}

Milgrom \& Roberts, (1992), identified the following CEO incentive programs: (1) Salary: Fixed amount paid over the course of the year. The salary can be changed from year to year based on length of service, previous performance, years of tenure, cost of living (inflation), or other considerations. (2) Bonus: A variable amount often paid as a lump sum at the end of the year, or the following year. The bonus is based on performance and is often tied to a certain performance criteria. A bonus is normally paid out if certain performance criteria or boundaries have been exceeded. (3) Stock Options: A stock option gives the CEO the right to purchase stock in the firm at a pre-set price that is at or above the current price of the stock. This offer is valid for a certain time period and will encourage the CEO to increase the stock price in order to earn the difference between the pre-set stock price and the future stock price. (4) (Restricted) Stock Awards: Restricted stock awards are shares given to the CEO, or sold to the CEO at a deep discount. Certain restrictions are tied to these stocks. These restrictions may imply that the stocks cannot be sold within a certain time horizon, or cannot be sold until certain performance criteria have been met.

Leonard (1990) argued that an incentive contract as a remuneration should be structured on the basis of the agent meeting specific "incentives" targets in the accomplishment of his or her contract.

The purpose of the incentive contracts is to motivate the agents' efforts and discourage the agents' inefficiency and waste. A form of incentive contract is a fixed price contract. It is such that a normal profit is included in the contract and an additional award fee may be rendered for excellent performance. Lambert and Larcker (1997) argued that if a greater percentage of 
the executive compensation is equity based, it will entice the CEO to take more risk-neutral decisions, which are in the best interest of the principal. In the instance of the contract, the period of performance must be long enough to align the top manager's interest with the interest of the principal. Incentive contracts usually encompass a base salary, annual cash incentives, equity-based incentives, and retirement plans. For the 260 companies being observed, $45 \%$ of their compensation packages are equity based. The base salary and annual cash incentive are short-term lump sums issued at the end of the financial year; the latter is dependent of performance criteria and may be paid in the following year. Equity based incentives are referred to as Long-term incentive plans (LTIP). They take the form of Stock option plan, restricted stock plan, phantom stock plan, deferred share units, and stock appreciation rights (SAR). The Stock Option Plan links compensation to shareholders' interests because the value of the inducement is directly related to the company's future stock price (Lewellen and Loderer, 1992). This plan's main objective is to give the option holder an interest in maximizing shareholder value over the long term. It enables the firm to attract and retain top managers with experience and ability while rewarding them for long-term performance. Stock option plan seems to be the preferred form of long-term incentive plans. The problem that may arise when using stock options as the pivotal element in an incentive contract is that contrary to the principal who can hedge away the risk of his or her option (i.e., trade the option, or short sell it) a CEO cannot take any of these actions on his stock option. In addition, while principals can diversify their assets, company executives cannot diversify away some of their risk since a large portion of their assets (i.e., salary taking the form of stock options) is invested in their company (Main et. al., 1996)

\section{Agency Theory and Incentive Compensation}

Agency theory suggests that compensation policy tying executive pay to corporate performance or shareholder wealth provides incentives for executives to exert appropriate efforts on behalf of shareholders. There are many mechanisms through which compensation policy can provide value-increasing incentives (McKnight and Tomkins, 1999). Executive compensation is one of those internal control mechanisms. Performance-based bonuses, share options and share ownership schemes are examples of incentive compensation schemes (Jensen \& Meckling, 1976; Jensen \& Murphy, 1990). Murphy (1996) argued that the quantum of compensation determines where executives work, and the compensation structure determines how hard they work. Shareholders who are well-diversified and risk-neutral are more likely to prefer a compensation package with maximum variability based on corporate performance. However, a risk-averse executive's natural tendency is to desire a compensation package with maximum certainty. Therefore, in deciding the extent to which the compensation is contingent on corporate performance, a balance must be struck between the interests of both shareholders and executives (Mehran, 1995). Innovations in compensation policy have received considerable attention in the past decade. These innovations have frequently sought to adjust the balance between long-term and more immediate forms of compensation, or between certain performance contingent elements. Although many different kinds of compensation schemes have been developed to mitigate the agency problem, this paper focuses on CEO cash compensation only. 


\section{1) Macrothink}

Business and Economic Research

ISSN 2162-4860

2016, Vol. 6, No. 2

\section{Managerial entrenchment and opportunistic behavior- "Empire Building"}

"Empire building" is a term used to refer to executives who do not act in the best interest of the shareholders, but rather try to expand the firm, and its domain at any price. As argued by Gomez- Meija et.al (1997), an executive left alone would rather try to maximize the corporate wealth instead of the shareholder wealth, unless the right incentives are given. In the thinking of Hart (1995), if managers are put on the right incentive scheme they will work to maximize shareholders' interest. In this sense, an incentive scheme might work as a motivating factor and boost the overall effort of the executive, but it will be less effective in getting executives to cut back on the "Empire building". This can be explained by the fact that executives with high "personal" ambitions are not willing to give up their plans to build up the size of the firm in order to increase the wealth of the shareholders. On the other hand, managerial entrenchment is a concept that involves whether a firm should be liquidated or not. It is a typical principal - agent problem since the best interest of the stockholders and the executives might be different. Under certain conditions the optimal decision for the stockholders might be to liquidate the firm in order to yield a certain pay-off. The executive's only goal is to avoid liquidation (Hart 1995). Liquidation would result in a more efficient solution for the shareholders since it would terminate a negative cash flow and allow shareholders to walk away with the value of remaining assets. However, a manager acts on behalf of his own best interest, in order to hold on to his position and the remuneration that comes with his/her job. Such a manager is not willing to bear the risk of being unemployed, even though that would be the better solution for the stockholders.

\section{Methodology}

The data is analyzed and tested using ordinary least squares (OLS) method; the standard multiple regression procedure to obtained models. T-test was conducted in order to test for significance. Before applying the appropriate model for each individual test, this paper tested for econometric problems such as heteroskedasticity and multi-collinearity in the dataset to secure a data that would lead to valuable results.

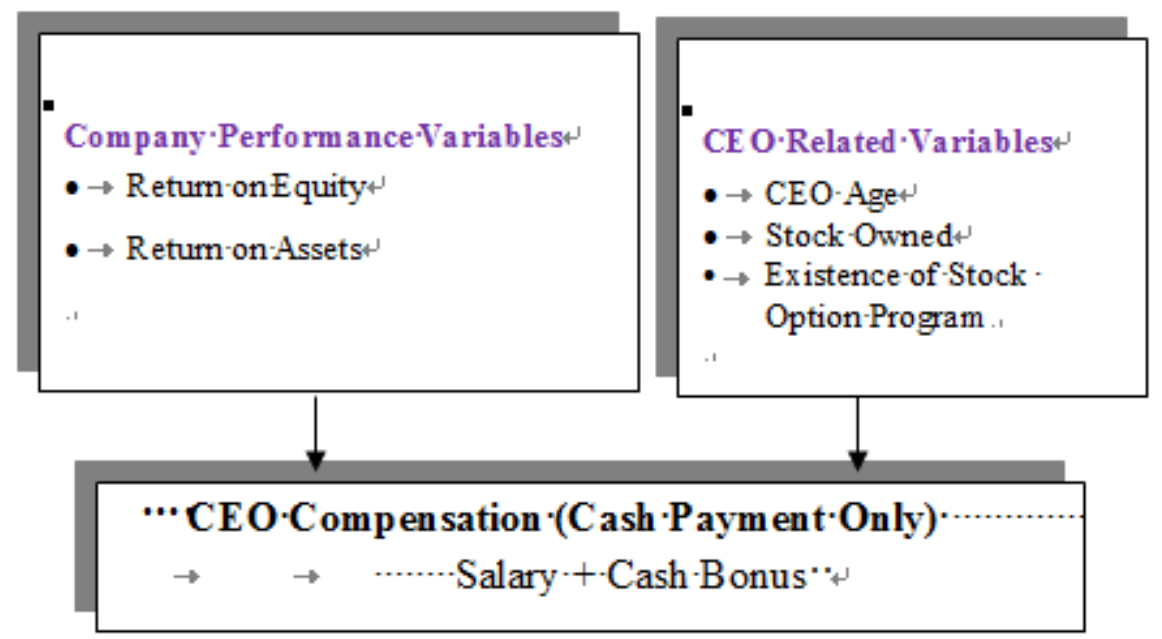

Figure 1. Study Model 
In this paper models that have been used in previous studies by Attaway (2000); Murthy and Salter (1975); Aupperle, Figler, and Lutz (1991); Akhigbe, Madura, and Tucker (1995); Madura, Martin, and Jessel (1996); and Hall, and Liebman (1998) have been modified and used as presented in Figure 1.

The companies listed on stock markets from Brazil, Mexico, South Africa and Poland, as at June 2015 are the target population of this analysis. Data was collected on the following variables; CEO age, CEO cash compensation: (fixed Salary, \& bonus), percentage of stock owned by CEO, ROE, ROA, existence of stock option program, industry Sector, and market value of shares, from 260 companies in nine industries identified. These industries were further grouped into four, consisting of companies in related industries. The second criterion requires the companies to have had the same CEO appointed for a four-year period (2011-2014). The application of this criterion has been set forth in order to make sure that a CEO has not been employed primarily to "save" a company under harsh financial conditions during the financial and economic crisis which started in 2008. Hiring a CEO primarily to "save" a company will most likely involve higher remuneration even in times of "bad" company performance. Therefore, a company that has gone through executive changes during the sample period has been eliminated. The data also includes small, medium, as well as large firms, since it provides the variation necessary to conduct statistical tests (Mehran, 2005).

Finally, the sample was restricted to "profit only" companies due to potential of loss making companies to add noise to the pay-to-performance relation. Ordinary Least Square (OLS) statistical method is used in order to test the hypotheses formulated. This method serves as the best linear unbiased estimator (B.L.U.E.) between two or more variables. Additionally, since more than one independent variable is involved, this paper has applied multiple regression analysis to explain variations in the dependent variable to obtain exact figures representing the statistical significance between the different relationships among the various variables. To examine the relationship between corporate performance and CEO cash compensation, the regression equation below is estimated on all 260 firms. The corporate performance proxies (CPP) are Return on Equity (ROE) and Return on Assets (ROA).

CEOcom $=a+b \mathrm{CPP}+c \mathrm{CEO}$ own $\%+d \mathrm{CEOstock}$ opt $+e \mathrm{CEO}$ age + dummy $+\mathrm{k}$,

Where: $\mathrm{CEOcom}=\mathrm{CEO}$ cash compensation,

$\mathrm{CPP}=$ Corporate performance proxies $(\mathrm{ROA}, \& \mathrm{ROE})$

CEOown $\%=$ CEO ownership percentage,

CEOstock opt $=$ Existence of stock option program

CEOage $=$ CEO age

\section{Qualitative Variables with Several Categories (Dummy Variables)}

Besides the variables shown in equation above, dummy variables were introduced to indicate the presence or absence of the related variable; existence of a stock option program for the 


\section{Macrothink}

CEO, industry sector, and company size. The dummies are defined as follow:

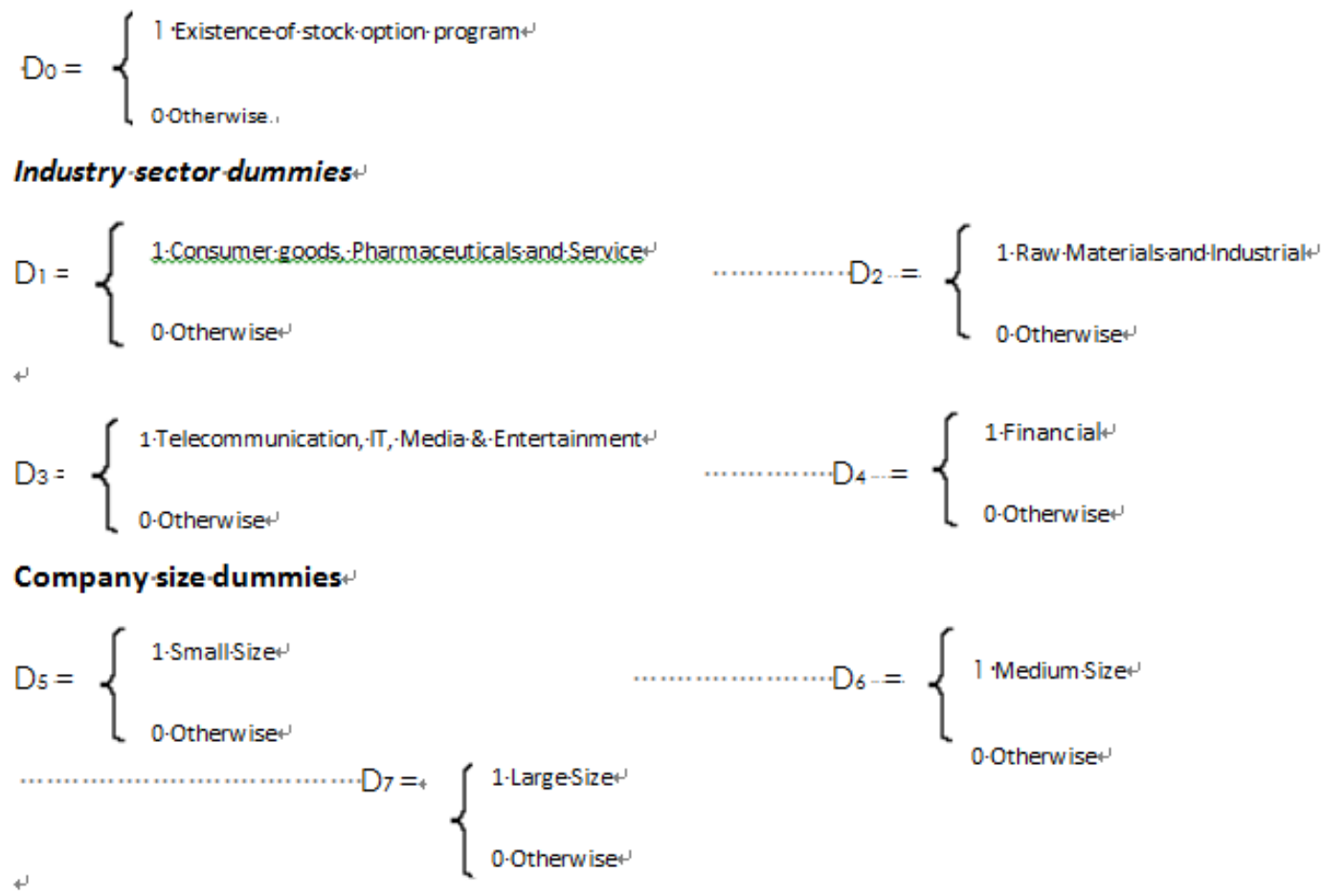

\section{Measurement of dependent, independent and control variables}

The dependent variable, corporate performance, is measured using two proxies: Return on equity (ROE) and Return on Assets (ROA). These two performance indicators are commonly used in studies on executive compensation. For each proxy of corporate performance, a four-year average $(2011$ - 2014) is calculated and used in the analysis. Economic Value Added (EVA) and Tobin's Q. are also important performance measures but were not used in this paper. ROE represents the ultimate measure of how well companies serve their shareholders' economic interests, so it is a typical performance benchmark in empirical studies. ROA provides information to the board about the value added to the company by the executives, which in turn affects their compensation. Therefore, executives have incentives to make corporate decisions, which improve ROA. The independent variables include the CEO cash compensation (salary \& bonus) and percentage of CEO share ownership. The proxy for CEO cash compensation (CEOcom) used is the euro amount of total annualized compensation received by the CEO. The compensation data is extracted from the annual reports of the companies, and the average is used. Share ownership is compensation that causes CEO's welfare to vary directly with corporate performance. Therefore, it is included as one of the independent variables. This variable is measured as the average percentage of the number of common shares owned by the CEO (CEOown\%). CEO cash compensation is not the only determinant of corporate performance. Therefore, in testing for the correlation between CEO compensation and corporate performance, three variables have been controlled: the existence of stock option program for CEO, company size, and Industry sector. For each control variable, four-year data from 2011 to 2014 were collected and average calculated. The market share of each company is used as a proxy for company. To be able to examine the 
relationship between firm performance and CEO compensation, two (2) hypotheses (H1 \& $\mathrm{H} 2$ ) were constructed and tested:

\section{H1: There is a significant correlation between CEO cash compensation and company performance}

\section{H2: No variables other than CEO cash compensation improves company performance}

Since CEO compensation and performance could be a counter-cyclical, it is important not to neglect the possibility that company performance may affect the CEO bonus, or might be a reason for increased performance. Hence, different econometric models were created to capture the different possible relationships between performance and compensation.

\section{H1: There is a significant correlation between $\mathrm{CEO}$ cash compensation and company performance}

$\mathrm{CEOcom}=\beta 1+\beta 2$ Age $+\beta 3 \mathrm{CEOown}+\beta 4 \mathrm{ROE}+\delta 0 \mathrm{D} 0+\delta 1 \mathrm{D} 1+\delta 2 \mathrm{D} 2+\delta 3 \mathrm{D} 3+\delta 4 \mathrm{D} 4+\delta 5 \mathrm{D} 5+\delta 6 \mathrm{D} 6+\delta 7 \mathrm{D} 7+\mathrm{e}$

CEOcom $=\beta 1+\beta 2$ Age $+\beta 3$ CEOown $+\beta 4 \mathrm{ROA}+\delta 0 \mathrm{D} 0+\delta 1 \mathrm{D} 1+\delta 2 \mathrm{D} 2+\delta 3 \mathrm{D} 3+\delta 4 \mathrm{D} 4+\delta 5 \mathrm{D} 5+\delta 6 \mathrm{D} 6+\delta 7 \mathrm{D} 7+\mathrm{e}$

Econometric Model 1: Comp. as dependent variable

\section{H2: No variables other than CEO cash compensation improves company performance}

$\mathrm{ROE}=\beta 1+\beta 2 \mathrm{Age}+\beta 3 \mathrm{CEO}$ wn $+\beta 4 \mathrm{CEO}$ com $+\delta 0 \mathrm{D} 0+\delta 1 \mathrm{D} 1+\delta 2 \mathrm{D} 2+\delta 3 \mathrm{D} 3+\delta 4 \mathrm{D} 4+\delta 5 \mathrm{D} 5+\delta 6 \mathrm{D} 6+\delta 7 \mathrm{D} 7+\mathrm{e}$

Econometric Model 2: ROE as dependent variable

$\mathrm{ROA}=\beta 1+\beta 2 \mathrm{Age}+\beta 3 \mathrm{CEO}$ own $+\beta 4$ CEOcom $+\delta 0 \mathrm{D} 0+\delta 1 \mathrm{D} 1+\delta 2 \mathrm{D} 2+\delta 3 \mathrm{D} 3+\delta 4 \mathrm{D} 4+\delta 5 \mathrm{D} 5+\delta 6 \mathrm{D} 6+\delta 7 \mathrm{D} 7+\mathrm{e}$

Econometric Model 3: ROA as dependent variable

\section{Testing for Heteroskedasticity and Multicollinearity}

The challenges with heteroskedasticity are dealt with in this study by plotting the residuals from the regression models. A pattern indicates heteroskedasticity, and as shown in Appendix $\mathrm{B}$, we were not able to detect any pattern in any of the four residual plots, indicating the absence of heteroskedasticity. This shows that the data does not contain any differences in the variance and as such no additional precautions are necessary in order to avoid heteroskedasticity. MacAvoy \& Millstein (2003) argue that a correlation between two variables that exceed 0.8 or 0.9 indicates a strong linear relationship that could cause eventual harm to the final results. In order to test for multi-collinearity, correlation matrix is constructed as shown in Appendix $\mathrm{C}$ that indicates that none of the variables are highly correlated, (no correlation of above 0.8 between any two pairs of variables).

\section{Empirical Result}

Table 1 provides summary descriptive statistics for the two measures of corporate performance, and the independent variables used in this study. ROE has a median of $-1.49 \%$ and a mean of $5.32 \%$. This suggests that very few firms had relatively high ROEs, while a 
large number of firms had very modest or poor returns. This conclusion is supported by the wide range of ROEs displayed, with a minimum of $-37.5 \%$ and maximum of $285.4 \%$. The median, mean, minimum, and maximum of ROA are $4.18 \%, 2.19 \%,-120.4 \%$, and $23.1 \%$, respectively. These ROA results also suggest that a few firms had relatively positive ROAs while most firms had modest negative ROAs. The annualized amount of CEO compensation (CEOcom) ranges from $€ 100$ to $€ 500$. The mean $(€ 349)$ is considerably higher than the median (€255), indicating that some CEOs are receiving much more than the median. Thus, the median figure is probably more representative of the market rate of CEO cash compensation.

Table 1. Descriptive Statistics of the Independent and Dependent Variables

\begin{tabular}{|c|c|c|c|c|c|}
\hline & Median & Mean & S.D. & Min & Max \\
\hline Corporate Performance Variables \\
\hline ROE (\%) & -1.494 & 5.326 & 41.121 & -37.554 & 285.4 \\
\hline ROA (\%) & 4.176 & 2.186 & 16.606 & -120.436 & 23.100 \\
\hline Control Variables & 255 & 349 & 290 & 100 & 500 \\
\hline CEOcom (€000) & $0.20 \%$ & $2.15 \%$ & $4.63 \%$ & $0.00 \%$ & $21.50 \%$ \\
\hline CEOown\%
\end{tabular}

The percentage of CEO share ownership ranges from $0.00 \%$ to $21.50 \%$. Analysis of the industry revealed that $50.68 \%$ of the companies are manufacturing, retailing, and pharmaceuticals. Approximately $34.25 \%$ of the companies are services, IT \& telecommunication and financial sector companies. While $15.07 \%$ are categorized as "others". These industries include resource-based companies in property development, property construction, and petroleum or mineral exploration.

\section{Overall Regression Results}

Table 6 shows the multiple regression results obtained by using ROE and ROA as proxies for firm performance. ROA regression model has f-statistic of 2.78; with adjusted R-squared $\left(\mathrm{r}^{2}\right)$ of 0.214 and is significant at the 0.05 percent level. However, when ROE is used, the regression is insignificant as the $f$-statistic is 0.20 and adjusted $\mathrm{R}$-squared $\left(\mathrm{r}^{2}\right)$ of -0.138 .

Table 2. Estimated Coefficients from Regression Analysis of Corporate Performance on Executive Compensation Variables and Control Variables

\begin{tabular}{|l|c|c|}
\hline & ROE & ROA \\
\hline Intercept & -0.116 & -0.369 \\
\hline CEOcom $(€ 000)$ & 0.000 & -0.000 \\
\hline CEOown\% & -0.765 & -1.124 \\
\hline FSIZE & 0.009 & -0.230 \\
\hline StOptDUM & 0.041 & -0.030 \\
\hline Ind1DUM & 0.007 & 0.146 \\
\hline Adjusted ${ }^{2}$ & -0.1384 & 0.214 \\
\hline F-statistics & 0.20 & 2.78 \\
\hline
\end{tabular}




\section{Results for the Independent Variables}

Table 2 shows that the estimated coefficient for CEO cash compensation (CEOcom) is not statistically significant at the 5 percent confidence level when corporate performance is measured in terms of ROE and ROA. With ROE as the proxy for corporate performance, the coefficient is positive but the magnitude is negligible. In ROA model, the coefficient is negative, but insignificant. Therefore, these two regression models exhibit no significant relation between CEO cash compensation and corporate performance, and the results suggest the rejection of hypothesis 1 . The coefficient of CEOown\% in the ROA regression is significant at 5\% confidence level. This finding indicates that the larger percentage of CEO share ownership is positively and significantly related to superior corporate performance. This result rejects hypothesis 2 and suggests that other variables than CEO cash compensation may affect company performance. This finding is consistent with Jensen and Meckling (1976) and Mehran (2005) that executives work harder and make meaningful decisions as their stake in the company increases. Higher percentage of ownership provides greater incentives to boost performance and CEO's willingness towards risk taking. However, hypothesis 2 is rejected when ROE is used as a dependent variable. The ROE regression coefficient has the negative sign but is statistically insignificant.

\section{Results for the Control Variables}

Additionally, Table 2 provides regression results for the control variables. In ROA regression the coefficient for company size is -0.230 and significant at the 5 percent level. This finding indicates that an increase in company size is associated with an increase in CEO Cash compensation. However, insignificant relation is found between company size and corporate performance. When ROE is used, insignificant result is also found between corporate performance and company size. This insignificant relationship is consistent with findings by Coughlam and Schmidt (2005) and Core et al. (2003). Both of these studies find no relationship between executive compensation and company size. The stock option program dummy variable (StOptDUM,) is found to have insignificant explanatory power for both corporate performance proxies. These consistent findings suggest that Hypothesis 2 is not rejected, indicating that there is no significant relationship between performance and adoption of stock option program by the CEO. The industry dummy variables are all found to be insignificant in the ROE regressions. However, CEOown\% and StOptDUM dummies are significant in the ROA regression. Since ROA is an accounting-based measure of corporate performance, these results may reflect similar accounting practices within the industry classes employed here.

\section{Does company performance or any other variables affect CEO bonus?}

When testing whether company performance or any other variables had any significant effect on CEO bonus, the result obtained from the econometric model indicates that none of the performance variables, ROE or ROA is of any significance for the dependent bonus variable at 0.05 significance level. This indicates that the performance of a company does not affect the magnitude of the compensation paid to the CEO. However, the percentage of outstanding shares owned by the CEO indicates a negative relationship to the bonus. This suggests that a higher percentage of ownership could motivate the CEO and create an incentive to perform 
well, since an increase in stock price will lead to increase in wealth for the CEO. This indicates a high percentage of ownership could act as an incentive for the CEO, and a bonus might not be considered necessary in such situation.

Table 2. Bonus as dependent variable

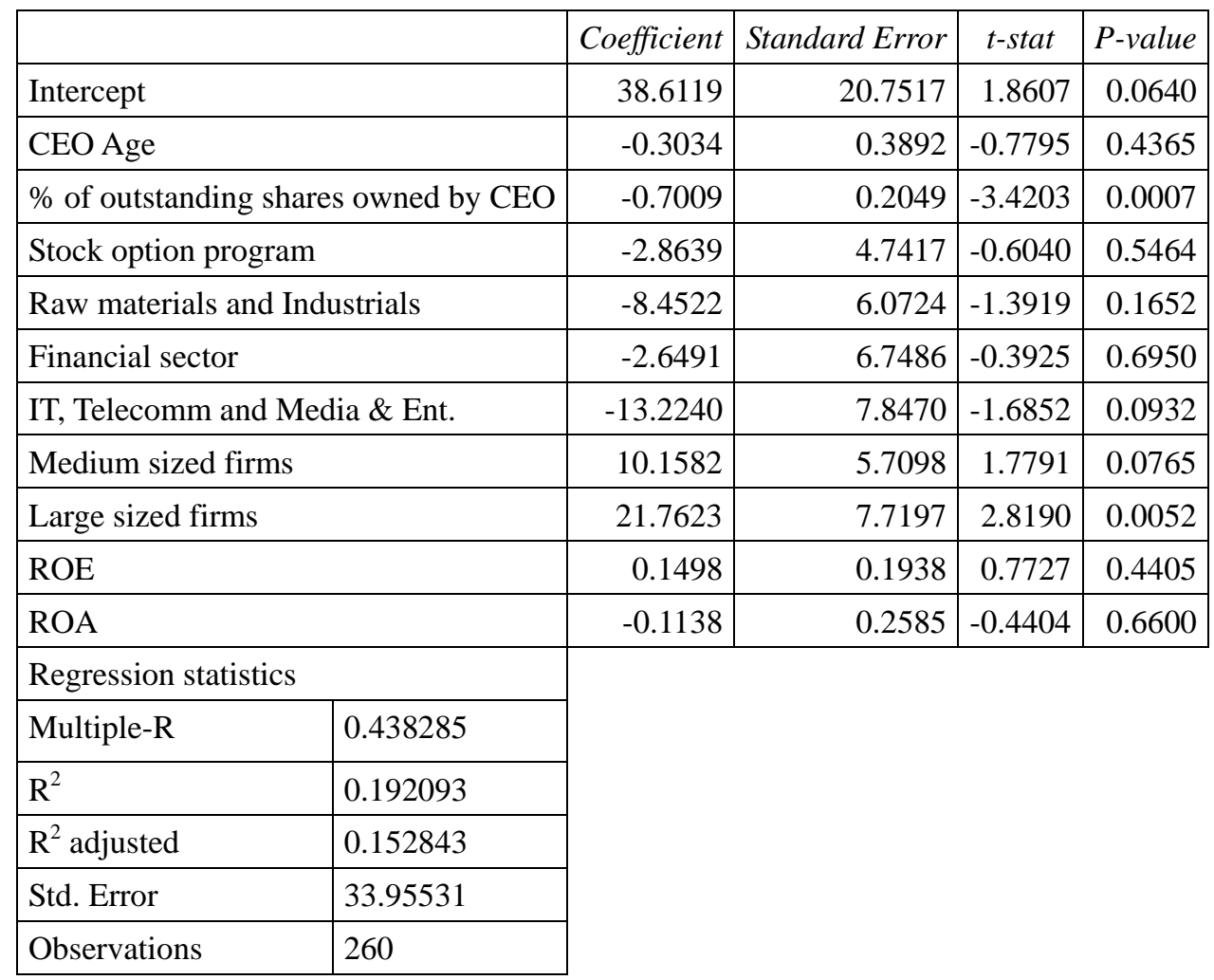

\section{Does bonus or any other variables affect company performance?}

To test whether bonus or any of the explanatory variables had any significant relationship with the performance of the company, the two performance variables were both tested separately. The results obtained are as follows:

ROE as dependent variable

\begin{tabular}{|l|l|l|l|l|}
\hline & Coefficient & Standard Error & t-stat & P-value \\
\hline Intercept & -11.779688 & 14.812333 & -0.795262 & 0.427218 \\
\hline \% Bonus + Base Salary & 0.036663 & 0.045467 & 0.806358 & 0.420806 \\
\hline CEO Age & 0.279715 & 0.276880 & 1.010239 & 0.313361 \\
\hline \% of outstanding shares owned by CEO & 0.005282 & 0.149483 & 0.035332 & 0.971843 \\
\hline Stock option program & -3.635189 & 3.375791 & -1.076841 & 0.282594 \\
\hline Raw materials and Industrials & 3.017164 & 4.302742 & 0.701219 & 0.483821 \\
\hline Financial sector & -7.201031 & 4.708413 & -1.529397 & 0.127435 \\
\hline IT, Telecom and Media \& Ent. & -12.281174 & 5.469409 & -2.245430 & 0.025618 \\
\hline Medium sized firms & 18.297189 & 3.938846 & 4.645318 & 0.000006 \\
\hline Large sized firms & 24.454476 & 5.339846 & 4.579622 & 0.000007 \\
\hline
\end{tabular}


Table 3: ROE as dependent variable

\begin{tabular}{|l|l|}
\hline \multicolumn{2}{|l|}{ Regression statistics } \\
\hline Multiple-R & 0.4365558 \\
\hline R2 & 0.1905814 \\
\hline R2 adjusted & 0.1580742 \\
\hline Standard Error & 24.305433 \\
\hline Observations & 260 \\
\hline
\end{tabular}

The result does not indicate whether bonus is having any impact on the ROE of a company. Neither does any of the other explanatory variables fall within the 0.05 significance level. The result indicates that the CEO base salary did not indicate a negative relationship with the performance variable ROE. This suggests that a high base salary does not necessarily serve as enough incentive for the CEO, since it may lead to shirking of responsibilities but at the same time enjoy his/her salary. However, it is difficult to draw any conclusions based on this result since the significance levels are partially fulfilled. Few of the dummy variables fall within the 0.05 significance level. When bonus and other explanatory variables were introduced into ROA econometric model, we found no significant relationship between CEO bonus and ROA at 5\% confidence level. However, the CEO base salary shows a weak negative significance on ROA.

\section{CEO Cash Compensation and Corporate Performance}

The association between CEO cash compensation and corporate performance measures and various relevant factors is studied using t-test. This test is conducted to investigate if there is any significant relationship between $\mathrm{CEO}$ cash compensation and company performance across different industrial sectors, and different company sizes. Hypothesis 1 posits that there is a correlation between CEO cash compensation and improved company performance among developing markets listed companies. The t-test is conducted using each proxy of company performance to determine if performance is significantly related to CEO cash compensation. Table 4 shows that the p-values of ROE and ROA are insignificant. These results provide evidence to support the alternative of hypothesis 1 that there is no relationship between CEO cash compensation and company performance among emerging market's listed companies. The null hypothesis is rejected. Hypothesis 2 is similarly tested by dividing firms into two samples on the basis of the median of CEO percentage of ownership (CEOown\%) and testing for a significant relationship with the performance measures. The uniformly significant results obtained suggest that the hypothesis of "no variables other than CEO cash compensation improve company performance" is rejected. This support the argument of agency theory, which maintains that corporate executives who hold relatively large ownership position in their firms will be motivated to achieve superior corporate performance. 
Table 4. Tests of relationship between CEO Cash Compensation, CEO Ownership Percentage, Corporate Performance Measures and Various Factors

\begin{tabular}{|l|l|l|l|}
\hline Two sample t-tests & Below Median & Above Median & p-value \\
\hline ROE based on CEOcom & $7.48 \%$ & $3.11 \%$ & 0.650 \\
\hline ROA based on CEOcom & $-0.89 \%$ & $5-34 \%$ & 0.108 \\
\hline ROE based on CEOown\% & $10.51 \%$ & $0.00 \%$ & 0.275 \\
\hline ROA based on CEOown\% & $4.14 \%$ & $0.17 \%$ & 0.318 \\
\hline CEOcom based on CEOown\% & $€ 1539.9$ & $€ 854.7$ & 0.006 \\
\hline CEOcom based on FSIZE (company size) & $€ 216.4$ & $€ 984.4$ & 0.000 \\
\hline CEOcom based on INDS (industry sector) & $€ 319.3$ & $€ 378.6$ & 0.388 \\
\hline CEOown\% based on FSIZE & $1.51 \%$ & $9.82 \%$ & 0.234 \\
\hline CEOown\% based on INDS & $1.39 \%$ & $1.52 \%$ & 0.669 \\
\hline
\end{tabular}

Table 4 also summarizes the results of the two-sample t-tests employing CEOcom and CEOown $\%$ and other control variables. In conducting these tests, all firms were grouped into two based on the market share (or the other variables, i.e., CEOown\%, StockOpt and Industry Sector). "Group A" includes companies with a market value less than (or equal to) the variable's median. "Group B" includes those companies with a market value greater than the median. A t-test is then used to determine if there is a significant difference between the mean CEOcom for the two groups. As shown in Table 4, the CEO compensation is found to be significantly associated with two of the independent and control variables (CEOown\%, and company size). The result of the two-sample t-test comparing CEO cash compensation and CEO ownership percentage is significant at the 5\% level. Interestingly, the mean CEOcom for firms with below-median CEOown\% is $€ 1539.9$ versus $€ 854.7$ for firms with above-median CEO share ownership. This suggests that the above-median CEOs may receive (a greater) proportion of their total remuneration in the form of share options. However, the existence of a stock-option program has a significant negative relationship to the percentage of CEO ownership (CEOown\%). This result was expected since these two variables are substitutes. These findings indicate that CEOs may be happier in receiving one form less than other. A higher percentage of other, for example, stock-option existence would motivate the CEO and create an incentive to perform well. An increase in stock price would lead to increase in CEO wealth. As a result, a higher percentage of ownership itself will not serve as enough incentive for the CEO.

\section{Company Size Effects}

The strong significant association (at the 5\% level) between firm size (FSIZE) and CEOcom, when ROA is used as performance proxy is what might be expected. The mean CEOcom for relatively small firms is $€ 216.4$ compared to the mean CEOcom of $€ 984.4$ for larger firms. This suggests that firm size is found to be the most significant characteristic associated with CEO cash compensation among the attributes analyzed. The p-values for both tests, i.e., based on share option scheme, and share ownership scheme, are less than 0.05 . The consistency of these results shows that as firms grow in size, so do the cash compensation for their CEOs. Larger companies are more significantly to have bigger relationship between 
good corporate performance and cash compensation schemes for CEOs than smaller companies. This finding also supports the argument that large companies are more innovative in designing their CEOs compensation. Hence, the suggestions that CEO compensation and company performance differs "depending upon the size of the company" cannot be rejected. However, when ROE is used as performance proxy for large companies, the coefficient is $(-0,002)$ suggesting a significant negative relationship between CEO cash compensation and corporate performance. This suggests that offering the CEO a higher salary alone may increase his or her unwillingness to take on additional risk and thereby decrease the execution of value maximizing decisions of the shareholders. Boards of directors have responsibilities to design incentive systems for CEOs that help firms achieve their goals. From the governance perspective, one of the critical roles of the board of directors is to align the CEO compensation with the interests of the owners of the corporation, which is the long-term shareholder returns. This is essentially because shareholders rely on CEOs to adopt policies and strategies that maximize the value of their shares.

\section{Industry Sector Effects}

The industry dummy variables are all found to be insignificant in the ROE regression. However, CEO share ownership (CEOown\%) is found to be significantly higher in certain industry sector with greater growth opportunities as proxied by ROE. This result suggests that CEOs are able to act on their inside information and are willing to hold larger stakes in firms they perceive to possess greater growth potential. When ROA is used as performance proxy, CEOown\% and the existence of a stock option program shows a significant negative relationship for all the industry sector dummy variables. The possible explanation is that, these incentive programs would work independently of cash compensation irrespective of the industry sector. The CEO would experience a sufficient payoff in times of good company performance, and his stock ownership will result in increased individual wealth. Furthermore, the CEO cash compensation (CEOcom) also indicates a negative significance for all the industry sector dummy variables. This suggests that higher cash compensation does not lead to increased corporate performance, since the CEO would shirk on his or her responsibility but collect his or her high cash compensation with no fear of losing his or her position.

\section{The CEO Age Effects}

The CEO age variable did not show any significance in any of the tests performed. This finding contradicts some of the theories arguing that an older CEO's ability to gain experience and specific knowledge, and its overall positive effect on company performance.

\section{Impact of CEO Compensation on Firm Performance}

Hypothesis 1 posits that there is a relationship between CEO cash compensation and improved corporate performance. Two sample t-tests were conducted using each proxy of corporate performance to determine if performance is significantly related to cash compensation. For both measures of corporate performance, the p-values are larger than 0.05 , indicating no significant relationship is identified at the $95 \%$ confidence level. The consistency of these results strongly suggests that the null hypothesis is rejected. The 
insignificant relationship between cash compensation and corporate performance challenges the effectiveness of using CEO's cash compensation to improve company's performance in the developing countries. This evidence suggests that the mere institution of many incentive compensation programs is not necessarily sufficient to control the principal-agency problem. These findings provide an evidence to support Heron and Lie (2009) argument that the propensity of incentive compensation programs to align the interests of shareholders and executives may depend on the ability to accurately measure performance, the monitoring system, and the extent to which the schemes match or reinforce the culture of the company.

\section{Correlation Analysis between the Independent and Control Variables}

Table 5 provides the correlation matrix between the independent and control variables. Three correlation coefficients are statistically significant at the 5\% level. These correlations are CEOcom vs. FSIZE, CEOcom vs. CEOown\%. One comparison, CEOown\% vs. existence of stock option (StOPt) is negatively significant at the 5\% level. The correlation coefficient between CEO compensation and company size equals +0.728 and indicates that this variable is highly and positively correlated.

Table 5. Correlation Matrix-Independent and Control Variables

\begin{tabular}{|l|l|l|l|l|l|}
\hline & CEOown\% & FSIZE & Stock Opt & Ind. Sec & CEOcom \\
\hline CEOcom & -0.167 & 0.728 & 0.302 & 0.166 & - \\
\hline CEOown\% & - & -0.213 & -0.085 & -0.064 & -0.083 \\
\hline FSIZE & - & - & 0.451 & 0.186 & 0.476 \\
\hline Stock Opt & - & - & - & -0.043 & 0.134 \\
\hline Ind. Sec & - & - & - & - & 0.069 \\
\hline
\end{tabular}

\section{Summary and Conclusion}

Executive compensation is regarded as an internal mechanism, which may help alleviate the agency problem between corporate managers and shareholders. Various innovative incentive and compensation schemes have been designed to tie executive pay to shareholder wealth. This paper examines the relationship between CEO cash compensation and corporate performance in emerging markets. Numerous studies on executive compensation schemes have been conducted in the United States and the United Kingdom, but evidence from other markets is more limited and non-existent for some emerging markets. These markets present a unique opportunity for the study of incentive compensations effects on company performance since corporate governance reforms and institution of executive compensation has only recently become mandatory. The use of compensation schemes is increasingly gaining acceptance in emerging markets and the principal objective of this paper is to analyze the significance of CEO cash compensation scheme on the corporate performance. The association between both CEO cash compensation and the percentage of shares owned by the Chief Executive Officer (CEO) and corporate performance is examined. Two sample t-tests between CEO cash compensation using a market-related, and an accounting-based performance measure, specifically, ROE, and ROA, were tested. No significant relationship is found between CEO cash compensation and these performance measures. However, this 
paper has found that CEO cash compensation is positively related to company size, a result that has not been found by the previous studies. We found that there is more extensive relationship between larger size companies and CEO cash compensations. The relationship between the percentages of shares owned by the CEO is found to be significantly associated with the two performance measures. The CEO share ownership and industrial sectors dummy are found to show a significant negative relation with stock option program. These findings are inconsistent with findings from US and UK empirical studies on executive compensation.

This paper has explored the effectiveness of using CEO cash compensation scheme in improving corporate performance in emerging markets. No clear significant relationship was found between the cash compensation and the two measures of corporate performance using t-tests. This suggests that companies that adopt cash compensation scheme for their CEOs do not perform better than companies without this compensation incentive in the emerging markets. The relationship between corporate performance, CEO cash compensation and executive share ownership is also investigated through multiple regressions. When ROE is used as the proxy for corporate performance, the relationship is positive but insignificant. The association between ROA and CEO cash compensation is also found to be negative and insignificant. These results do indicate that there is no clear relationship between CEO cash compensation and corporate performance among the listed companies in this study.

Conclusively, this paper has found no evidence to suggest that there is a significant relationship between CEO cash compensation and corporate performance among listed companies included in this study. We also found that stock market performance tends to play a less important role in the determination of the CEO compensation. This suggests that cash compensation does not seem to provide any better incentive effect and therefore higher cash compensation alone would not have an impact on corporate performance. This could be due to the fact that CEO compensation in general is determined by considerations which are not related to shareholders interests. Both of the hypotheses formulated were rejected for the companies in this study. However, company size (FSIZE) measured by sales and assets is found to be an important factor affecting CEO compensation. The larger the company, the higher the compensation which is not linked to any corporate performance. This finding is consistent and provides an evidence to support the managerialist theories that executives have incentives to maximize firm sales rather than profits. This may also suggest that CEOs in larger firms may however increase their compensation by deliberately increasing the firm size, even when the increase in size reduces the firm's market value. This supports Ciscel and Carroll (2009) argument that the growth of firm size is an important method for the CEO to increase profitability.

\section{Reference}

Agawal, A., \& Mandelker, G. N. (1987). Managerial Incentives and Corporate Investment and Financing Decisions. Journal of Finance, 42(4), 823-837. http://dx.doi.org/10.1111/j.1540-6261.1987.tb03914.x

Akhigbe, S., Madura, J., and Tucker, A.L., (1995). Reexamining the link between executive compensation and corporate performance: A note. American Business Review, 13, 2-83. 
Attaway, M. C., (2000). A study of the relationship between company performance and CEO compensation. American Business Review, January: 77-85.

Aupperle, K. E., Figler, R. A., \& Lutz, R. C., (1991). Do the in search of excellence firms effectively match CEO compensation to corporate performance? Journal of Managerial Issues, III(4), 444-457.

Bebchuk, L., Fried J., (2004). Pay without Performance, Unfulfilled Promise of Executive Compensation, Harvard University Press

Boyd, B.K., (1994). Board control and CEO compensation. Strategic Management Journal, 15(5), 335. http://dx.doi.org/10.1002/smj.4250150502

Ciscel, D. H., \& Carroll, T. M., (2009). The Determinants of Executive Salaries: An Econometric Survey. The Review of Economics and Statistics, 62(1), 7-13. http://dx.doi.org/10.2307/1924267

Core J. E., Guay W. R., Larcker D. F., (2003). Executive equity compensation and incentives: a survey. Fed. Reserve Bank N.Y. Econ. Policy Rev, 9(1), 27-50

Coughlan, A. T. \& Schmidt, R. M. (1995). Executive compensation, management turnover, and firm performance: An empirical investigation. Journal of Accounting and Economics, $7(1 / 3), 43$

Dess, G. G., Lumpkin, G. T., \& Eisner, A. B. (2008). Strategic management: Creating competitive advantages. (4th ed.). New York: McGraw-Hill Publishers.

Eisenhardt, K. M. (1989). Agency theory: An Assessment and Review. Academy of Management Review, 14(1), 57-74.

Gomez-Meija, L. R., Tosi, H., \& Hinkin, T., (1997). Managerial control, performance, and executive compensation. Academy of Management Journal, 30(1), 51-70. http://dx.doi.org/10.2307/255895

Goulter, J. (1996). Performance pay-Is your company scheme on target? New Zealand Business, 10(4), 12-19.

Grossman, S. J., \& Hart, O. D., (1983). An analysis of the principal agency problem. Econometric, 51, 7-45. http://dx.doi.org/10.2307/1912246

Hall, B. J., \& Liebman, J. B., (1998). Are CEOs really paid like bureaucrats? Quarterly Journal of Economics, August: 653. http://dx.doi.org/10.1162/003355398555702

Harris, M., \& Raviv, A., (1979). Optimal incentive contracts with imperfect information. Journal of Economic Theory, 20, 231-259. http://dx.doi.org/10.1016/0022-0531(79)90073-5

Hart, O., (1995). Firms Contracts and Financial Structure, Clarendon Press, Oxford. http://dx.doi.org/10.1093/0198288816.001.0001

Holmstrom, B., (1979). Moral hazard and observability. Bell Journal of Economics 10, spring, 74-91. http://dx.doi.org/10.2307/3003320 
Heron RA, \& Lie E. (2009). What fraction of the stock option grants to top executives have been backdated or manipulated? Manag. Sci. 55(4), 513-25. http://dx.doi.org/10.1287/mnsc.1080.0958

Jensen, M. C., \& Meckling, W. (1976). Theory of the firm: Managerial behavior, agency costs and ownership structure. Journal of Financial Economics, 3, 305-360. http://dx.doi.org/10.1016/0304-405X(76)90026-X

Jensen, M. C., \& Murphy, K. J., (1990). Performance pay and top-management incentives. Journal of Political Economy, 98, 225-264. http://dx.doi.org/10.1086/261677

Lambert, R. A. \& Larcker, D. F. (1997). An analysis of the use of accounting and market measures of performance in executive compensation contracts. Journal of Accounting Research, 25, 85-125. http://dx.doi.org/10.2307/2491081

Leonard, J. S. (1990). Executive pay and firm performance. Industrial and LaborRelations Review, 43(3), 13-29. http://dx.doi.org/10.1177/001979399004300302

Lewellen W. G. \& Huntsman, B. (1970). Managerial pay and corporate performance. American Economic Review, 60, 710-720.

Lewellen, W. G., Loderer, C., Martin, K., \& Blum, G. (1992). Executive compensation and the performance of the firm. Managerial and Decision Economics, 13(1), 65-74. http://dx.doi.org/10.1002/mde.4090130108

MacAvoy, P. W., \& Millstein, I. M., (2003). The Recurrent Crisis in Corporate Governance, Palgrave Macmillan Inc, USA. http://dx.doi.org/10.1057/9781403946881

Madura, J., Martin, A. D., \& Jessel, K. A., (1996). Determinants of CEO compensation in small publicly-traded businesses. American Business Review, 14, 80-88.

Main, B. G. M., Bruce, A., \& Buck, T. (1996). Total board remuneration and company performance. Economic Journal, 106(439), 1627-1644. http://dx.doi.org/10.2307/2235204

McKnight, P. J., \& Tomkins, C. (1999) Top executive pay in the United Kingdom: A corporate governance dilemma. International Journal of the Economics of Business, 6(2), 223-243. http://dx.doi.org/10.1080/13571519984241

Mehran, H., (2005). Executive compensation structure, ownership, and firm performance. $\begin{array}{lllll}\text { Journal of } & \text { Financial } & \text { Economics, } & 38, & 163-184 .\end{array}$ http://dx.doi.org/10.1016/0304-405X(94)00809-F

Milgrom P., \& Roberts J., (1992). Economics, Organizations \&Management, Prentice-Hall Inc., New Jersey, USA

Murphy, K. J. (1996). Reporting Choice and the 1992 Proxy Disclosure Rules, Journal of Accounting, Auditing, and Finance, 11(3), 497-515.

Ross, S. A., Westerfield, R. W., \& Jaffe, J. F., (2002). Corporate Finance, 6th Edition, Mc Graw-Hill, Irwin, USA 


\section{Macrothink}

Business and Economic Research

ISSN 2162-4860

2016, Vol. 6, No. 2

\section{Appendix A}

\begin{tabular}{|c|c|c|}
\hline \multicolumn{3}{|c|}{ Summary of Sources and Definition of Variables } \\
\hline Variables & Data Source & Measured As: \\
\hline \multicolumn{3}{|l|}{ Dependent Variables } \\
\hline ROE & $\begin{array}{l}\text { Annual } \\
\text { Reports }\end{array}$ & $\begin{array}{l}\text { Return on equity is defined as (closing share price }+ \text { dividends }- \\
\text { opening share price) / opening share price. }\end{array}$ \\
\hline ROA & $\begin{array}{l}\text { Annual } \\
\text { Reports }\end{array}$ & $\begin{array}{l}\text { Return on assets is measured as the ratio of net income to book value of } \\
\text { total assets. }\end{array}$ \\
\hline \multicolumn{3}{|l|}{ Independent Variables } \\
\hline CEOcom & $\begin{array}{l}\text { Annual } \\
\text { Reports }\end{array}$ & $\begin{array}{l}\text { The cedi amount of total compensation and other benefits received by } \\
\text { the CEO. }\end{array}$ \\
\hline CEOown \% & $\begin{array}{l}\text { Annual } \\
\text { Reports }\end{array}$ & $\begin{array}{l}\text { The total common share holdings of the CEO as a percentage of total } \\
\text { common shares outstanding. }\end{array}$ \\
\hline \multicolumn{3}{|l|}{ Control Variables } \\
\hline $\begin{array}{l}\text { STOpt (existence of } \\
\text { stock option) }\end{array}$ & $\begin{array}{l}\text { Annual } \\
\text { Reports }\end{array}$ & $\begin{array}{l}\text { The portion of CEO remuneration as equity based through incentive } \\
\text { stock options. }\end{array}$ \\
\hline FSIZE (company size) & $\mathrm{CSO}^{*}$ & Company size is measured as the market share or total assets. \\
\hline INDS (industry sector) & $\mathrm{CSO}^{*}$ & $\begin{array}{l}\text { A dummy variable equal to one if the company is in the nine mentioned } \\
\text { industries, and otherwise equal to zero. }\end{array}$ \\
\hline
\end{tabular}

\section{Appendix B}

\section{Residual plots in order to test for heteroskedasticity}

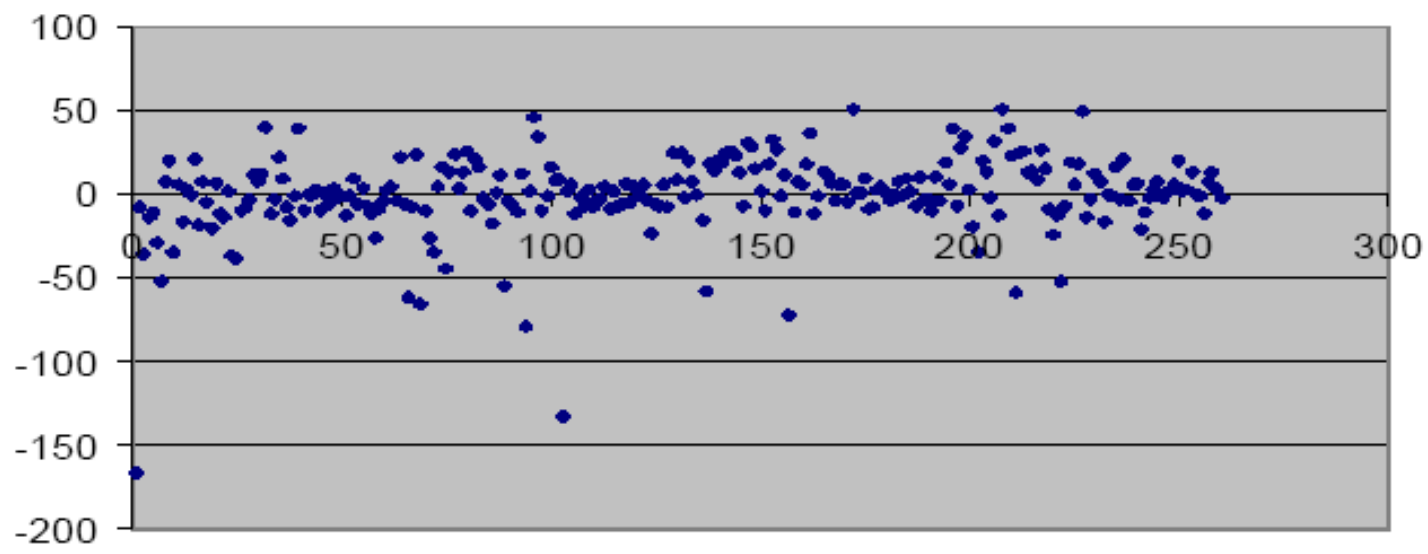

\section{ROE as Dependent Variable}




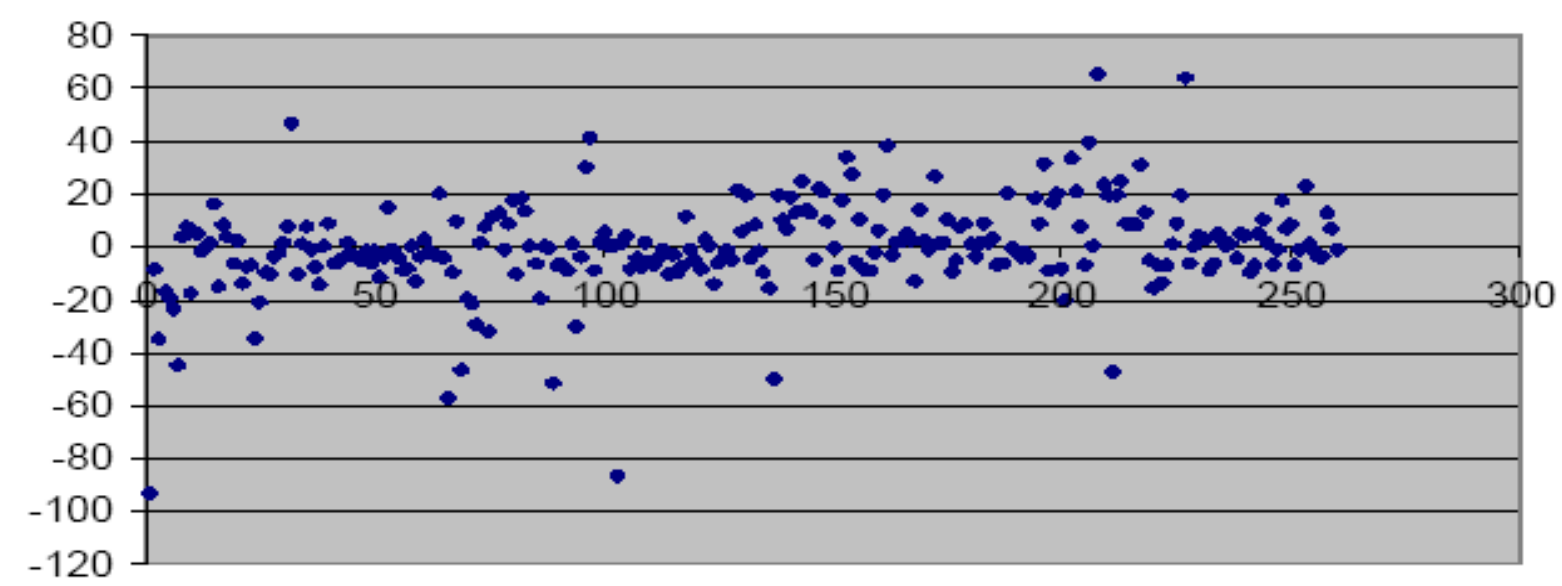

\section{ROA as Dependent Variable}

\section{Appendix C}

\begin{tabular}{|c|c|c|c|c|c|c|c|c|c|c|c|c|c|}
\hline & $\mathbf{1}$ & $\mathbf{2}$ & $\mathbf{3}$ & $\mathbf{4}$ & $\mathbf{5}$ & $\mathbf{6}$ & $\mathbf{7}$ & $\mathbf{8}$ & $\mathbf{9}$ & $\mathbf{1 0}$ & $\mathbf{1 1}$ & $\mathbf{1 2}$ & $\mathbf{1 3}$ \\
\hline $\mathbf{1}$ & 1 & 0.03 & -0.29 & 0.02 & -0.01 & 0.08 & 0.08 & -0.17 & -0.30 & -0.02 & 0.32 & 0.16 & 0.11 \\
\hline $\mathbf{2}$ & 0.03 & 1 & -0.16 & 0.02 & 0.34 & -0.17 & 0.08 & -0.31 & -0.02 & -0.03 & 0.05 & 0.14 & 0.06 \\
\hline $\mathbf{3}$ & -0.29 & -0.16 & 1 & -0.18 & -0.09 & 0.13 & -0.03 & 0.00 & 0.33 & -0.13 & -0.20 & -0.11 & -0.10 \\
\hline $\mathbf{4}$ & 0.02 & 0.02 & -0.18 & 1 & 0.06 & -0.17 & -0.04 & 0.17 & -0.11 & -0.03 & 0.14 & -0.07 & -0.06 \\
\hline $\mathbf{5}$ & -0.01 & 0.34 & -0.09 & 0.06 & 1 & -0.44 & -0.38 & -0.36 & -0.08 & -0.01 & 0.08 & 0.19 & 0.19 \\
\hline $\mathbf{6}$ & 0.08 & -0.17 & 0.13 & -0.17 & -0.44 & 1 & -0.29 & -0.27 & -0.11 & -0.03 & 0.14 & -0.04 & -0.14 \\
\hline $\mathbf{7}$ & 0.08 & 0.08 & -0.03 & -0.04 & -0.38 & -0.29 & 1 & -0.24 & 0.13 & -0.20 & 0.07 & 0.03 & -0.01 \\
\hline $\mathbf{8}$ & -0.17 & -0.31 & 0.00 & 0.17 & -0.36 & -0.27 & -0.24 & 1 & 0.08 & 0.25 & -0.33 & -0.23 & -0.08 \\
\hline $\mathbf{9}$ & -0.30 & -0.02 & 0.33 & -0.11 & -0.08 & -0.11 & 0.13 & 0.08 & 1 & -0.51 & -0.49 & -0.32 & -0.30 \\
\hline $\mathbf{1 0}$ & -0.02 & -0.03 & -0.13 & -0.03 & -0.01 & -0.03 & -0.20 & 0.25 & -0.51 & 1 & -0.49 & 0.11 & 0.14 \\
\hline $\mathbf{1 1}$ & 0.32 & 0.05 & -0.20 & 0.14 & 0.08 & 0.14 & 0.07 & -0.33 & -0.49 & -0.49 & 1 & 0.22 & 0.16 \\
\hline $\mathbf{1 2}$ & 0.16 & 0.14 & -0.11 & -0.07 & 0.19 & -0.04 & 0.03 & -0.23 & -0.32 & -0.11 & -0.22 & 1 & 0.79 \\
\hline $\mathbf{1 3}$ & 0.11 & 0.06 & -0.10 & -0.06 & 0.19 & -0.14 & -0.01 & -0.08 & -0.03 & 0.14 & 0.16 & 0.79 & 1 \\
\hline
\end{tabular}




\section{Table XX: Correlation Matrix}

1. $\%$ Bonus + Base Salary

2. CEO Age

3. \% of Outstanding Stock Owned by CEO

4. Stock Option Program

5. Raw Materials \& Industrials

6. Financial

7. Consumer Goods, Pharmaceuticals, \& Service

8. IT, Telecommunication, and Media \& Entertainment

9. Small Sized Firms

10. Medium Sized Firms

11. Large Sized Firms

12. ROE

13. ROA

\section{Copyright Disclaimer}

Copyright for this article is retained by the author(s), with first publication rights granted to the journal.

This is an open-access article distributed under the terms and conditions of the Creative Commons Attribution license (http://creativecommons.org/licenses/by/3.0/). 